\title{
HUBUNGAN PROFESIONALISME GURU DENGAN HASIL BELAJAR SISWA DI SMPN 1 NANGGUNG BOGOR
}

\author{
Muhamad Ropi' ${ }^{1)}$, Chaira Sadiah ${ }^{2)}$, Yusi Prihartini ${ }^{3)}$ \\ Fakultas Tarbiyah, IAI Nasional Laa Roiba Bogor \\ ropimuhammad@gmail.com \\ ira_yusrie@yahoo.com \\ yusisrihartini5@gmail.com
}

\begin{abstract}
In the learning process, student learning outcomes can relate to the professionalism of the teacher. This study aims to determine the level of professionalism of class VIII Islamic education teachers at SMPN 1 Nanggung, to determine the level of PAI learning outcomes of grade VIII students of SMPN 1 Nanggung and to determine the professionalism relationship between teachers of slamic education and learning outcomes of grade VIII students of SMPN 1 Nanggung. This research is a quantitative descriptive study with the X1 variable being the professionalism of the teacher, the X2 variable being the PAI teacher professionalism and the $Y$ variable being the Student Learning Outcomes. The number of students was 76 out of 260 students. Data were collected using documentation and questionnaire methods. The validity of the questionnaire instrument was carried out by analyzing the items using the Product Moment correlation formula and the reliability test using the Cronbach Alpha formula. The results showed that: there is a positive and significant relationship between the professionalism of the PAI subject teachers and the learning outcomes of the VIII grade students of SMPN 1 Nanggung, a correlation coefficient of 0.242 with a sig value of 0.019 means that there is a significant positive relationship between teacher professionalism and student learning outcomes. The strong relationship between professionalism and learning outcomes is in the low category. Thus the test shows "there is a significant relationship between the professionalism of Islamic education teachers with the learning outcomes of grade VIII students of SMPN 1 Nanggung with a low category.
\end{abstract}

Keywords: Teacher Professionalism, Learning Outcomes, Learning.

Abstrak

Dalam proses pembelajaran, hasil belajar siswa dapat berhubungan dengan profesionalisme gurunya. Penelitian ini bertujuan untuk mengetahui tingkat profesionalisme guru PAI kelas VIII di SMPN 1 Nanggung, mengetahui tingkat hasil belajar PAI siswa kelas VIII SMPN 1 Nanggung, dan mengetahui hubungan profesionalisme guru mata pelajaran pendidikan agama islam dengan hasil belajar siswa kelas VIII SMPN 1 Nanggung. Penelitian ini merupakan penelitian deskriptif kuantitatif dengan variabel $X 1$ adalah profesionalisme guru, variabel X2 adalah profesionalisme guru PAI dan variabel Y adalah hasil belajar siswa. Dengan jumlah siswa 76 dari 260 siswa. Data diambil dengan menggunakan metode dokumentasi dan angket. Validitas instrumen angket dilakukan dengan analisis butir menggunakan rumus korelasi Product Moment dan uji reliabilitas menggunakan rumus Cronbach Alpha. Hasil penelitian menunjukkan bahwa ada hubungan positif dan signifikan antara profesionalisme guru mata pelajaran PAI dengan hasil belajar siswa kelas VIII SMPN 1 Nanggung dimana diperoleh nilai koefisien korelasi sebesar 0,242 dengan nilai sig 0,019, artinya terdapat hubungan positif yang sig antara profesionalisme guru dengan hasil belajar siswa. Hubungan antara profesionalisme dengan hasil belajar ada pada kategori rendah. Dengan demikian pengujian menunjukkan "terdapat hubungan yang signifikan antara profesionalisme guru PAI dengan hasil belajar siswa kelas VIII SMPN 1 Nanggung dengan kategori rendah.

Kata kunci : Profesionalisme Guru, Hasil Belajar.Pembelajaran.

PENDAHULUAN

Pendidikan umumnya berarti

daya upaya untuk meajukan

bertumbuhnya budi pekerti (kekuatan batin, karakter). Pikiran (intellect) dan

tubuh anak; dalam pengertian taman

siswa tidak boleh dipisah-pisahkan

bagian-bagian itu, agar supaya kita 
dapat memajukan kesempurnaan hidup,

yakni kehidupan dan penghidupan anak-anak yang kita didik selaras dengan dunianya (Ki Hadjar

Dewantara,2013).

Guru adalah pendidik

profesional dengan tugas utama mendidik, mengajar, membimbing, mengarahkan, melatih, menilai, dan mengevaluasi hasil pembelajaran siswa. profesionalisme guru ditandai dengan keahlian dibidang pendidikan. Guru juga sebagai pemegang jabatan professional yakni membawa misi ganda yang bersamaan, yaitu misi agama dan misi ilmu pengetahuan.. Misi agama menuntut guru untuk menyampaikan nilai-nilai ajaran agama kepada anak didik,sehingga anak didik dapat menjalankan kehidupan sesuai dengan norma-norma agama tersebut. Misi ilmu pengetahuan menuntut guru menyampaikan ilmu sesuai perkembangan kehidupan.
Peranan guru disekolah ditentukan oleh kedudukannya sebagai orang dewasa, sebagai pengajar dan pendidik dan sebagai pegawai. Yang paling utama ialah kedudukannya sebagai pengajar dan pendidik yakni sebagai guru. Berdsarkan kedudukannya sebagai guru ia harus menunjukkan kelakuan yang layak lagi bagi guru menurut harapan masyarakat (Nasution, 2011).

Guru adalah salah satu unsur dalam sistem dan memiliki peran yang sangat penting. Tuntunan yang berkualitas merupakan kewajiban agar proses pembelajaran berkualitas pula. Dengan kata lain, guru merupakan salah satu komponen yang sangat berpengaruh terhadap terciptanya proses pendidikan yang berkualitas. Oleh karena itu, diperlukan sosok guru mempunyai kualifikasi, kompetensi serta dedikasi yang tinggi dalam melaksanakan tugasnya sebagai 
pendidik yang profesional. Sehingga

istilah yang kita kenal sehari-hari bahwa

guru merupakan orang yang harus

digugu dan ditiru dalam artian orang yang memiliki kharisma dan wibawa, memang untuk ditiru dan diteladani.

Konsep islami menyatakan, guru profesional bukan hanya ahli, bisa,disiplin,dan akuntabel saja, tetapi juga harus didasari bahwa guru dalam tugasnya sebagai ibadah kepada Allah SWT, sebagai perintah-Nya, karena itu dalam melaksanakan profesinya guru dilandasi dengan keimanan, ketakwaan,dan keiksanan kepada Tuhan Robbal Alamin di samping harus menjadi suri tauladan,artinya guru terlebih dahulu berhakhlak karimah, agar menjadi rujukan muridnya dalam sifat,sikap serta perilakumya (Pupuh Fathurohman \& Aa Suryana, 2012).

Dalam kurikulum berbasis kompetensi 2004 terdapat empat komponen pokok, yaitu kurikulum dan hasil belajar,penilaian berbasis kelas, kegiatan belajar-mengajar, dan pengelolaan kurikulum berbasis sekolah. Dalam komponen kurikulum dan hasil belajar, setiap mata pelajaran terdapat tiga komponen penting, yaitu kompetensi dasar,hasil belajar, dan indikator pencapaian hasil belajar.

Kompetensi menentukan apa yang harus dilakukan peserta didik untuk mengerti, menggunakan, meramalkan, menjelaskan, mengapresiasi atau menghargai. Kompetensi adalah gambaran umum tentang apa yang dapat dilakukan peserta didik. Cara menilai seorang peserta didik sudah meraih kompetensi tertentu secara tidak langsung digambarkan di dalam pernyataan tentang kompetensi, sedangkan rincian tentang apa yang diharapkan dari peserta didik digambarkan dalam hasil belajar dan indikator. 
Penilaian proses belajar mengajar bertujuan mengetahui keberhasilan perencanaan kegiatan belajar mengajar yang telah disusun dan dilaksanakan.penilaian ini menentukan baik-tidaknya organisasi program atau kegiatan yang dilaksanakan untuk mencapai tujuan yang telah ditetapkan (Hamdani, 2011).

Pembelajaran yang berkualitas hanya dapat diwujudkan oleh guru yang memiliki kemampuan unggul dan motivasi yang tinggi dalam melaksanakan kewajibannya. Melalui pembelajaran yang berkualitas akan menghasilkan lulusan yang berkualitas pula. Demikian pula sebaliknya, jika pembelajaran yang dikelola guru tidak berkualitas, lulusannya tidak akan berkualitas. Hal tersebut akan berdampak pada kemampuan lulusan dalam menghadapi persaingan hidup yang semakin ketat.
Dari uraian diatas menunjukkan bahwa seorang guru dituntut untuk mempunyai profesionalisme yang tinggi, karena seorang guru merupakan tumpuan dari berhasil tidaknya suatu proses belajar mengajar dan selanjutnya akan menghasilkan output yang sesuai harapan. Dengan demikian tujuan dari penelitian ini adaah untuk menemukan hubungan profesionalisme guru dengan hasil belajar PAI Kelas VIII SMPN 1 Nanggung Kecamatan Nanggung Kabupaten Bogor.

\section{KAJIAN TEORI}

Menurut Sudjana (2004) hasil belajar adalah kemampuan-kemampuan yang dimiliki siswa setelah menerima pengalaman belajarnya. Menurut Oemar Hamalik (2006) hasil belajar adalah bila seseorang telah belajar akan terjadi perubahan tingkah laku pada orang tersebut. Misalnya dari tidak tahu menjadi tahu, dan dari tidak mengerti 
menjadi mengerti (Dedy Kustawan, 2013).

Dari seluruh pemaparan diatas, dapat dipahami Hasil Belajar merupakan kemampuan yang di peroleh peserta didik setelah melakukan proses pembelajaran yang menciptakan hasil dengan adanya perubahan dari segi prilaku serta kemampuan peserta didik.

1. Domain Hasil Belajar

Benyamin S.Bloom, dkk. mengemukakan hasil belajar di kelompokkan ke dalam tiga doamain, yaitu domain kognitif, domain efektif, dan domain psikomotor.
a. Domain kognitif
b. Domain Afektif
c. Domain psikomortor

2. Tujuan Evaluasi Hasil Belajar Tujuan dalam pendidikan dan pengajaran adalah suatu cita cita yang bernilai normative. Dengan perkataan lain, dalam tujuan terdapat sejumlah nilai yang harus ditanamkan kepada peserta didik. Nilai-nilai itu nantinya akan mewarnai cara anak didik bersikap dan berbuat dalam lingkungan sosialnya, baik disekolh maupun diluar sekolah.

Tujuan evaluasi hasil belajar dapat dilihat dari dua segi, yaitu tujuan umum dan tujuan khusus. L.Pasaribu dan simanjutntak menegaskan bahwa

a. Tujuan umum

1) Mengumpulkan data data yang membuktikan taraf kemajuan peserta didik dalam mencapai tujuan yang diharapkan

2) Memungkinkan pendidik menilai aktivitas yang didapat

b. Tujuan khusus

1) Merangsang kegiatan siswa

2) Menemukan sebab-sebab kemajuan dan kegagalan peserta didik

3) Memperoleh bahan laporan tentang perkembangan siswa 
yang diperlukan orangtua dan lembaga pendidikan

4) Untuk memperbaiki mutu pelajaran/cara belajar dan metode mengajar (Syaiful Bahri Djamarah dan Aswan Zain, 2010).

3. Faktor-faktor yang mempengaruhi Hasil Belajar

Secara global, factor factor yang mempengaruhi Hasil Belajar siswa dapat dibedakan menjadi tiga macam, yakni :

a. Faktor Internal (faktor yang berasal dari dalm diri siswa), yakni keadaan/kondisi dan rohani siswa,

b. Faktor Eksternal ( faktor yang berasal dari luar diri siwa), yakni kondisi lingkungan disekitar siswa,

c. Faktor pendekatan Belajar (approach to learning), yakni jenis upaya belajar siswa yang meliputi strategi dan metode yang digunakan siswa untuk melakukan kegiatan mempelajari materimateri pelajaran (Muhibbin syah, 129).

Dari beberapa factor diatas, dapat diketahui bahwa hasil belajar seorang siswa dapat dipengaruhi oleh bebrapa faktor-faktor tertentu yang dapat mempengaruhi hasil belajar tersebut. Selain itu, faktor diatas merupakan gambaran dan solusi dalam menjalani proses belajar agar pencapaian keberhasilan disekolah dapat dirasakan oleh semua siswa. Dengan demikian, faktor belajar haruslah sangat diperhitumgkan dalam proses belajar mengjar dikelas, karena jika factor itu tidak diperhatikan dengan baik, maka tentu hasil belajar siswa pun tidak akan tercapai dengan baik.

\section{METODOLOGI PENELITIAN}


Metode penelitian pada dasarnya merupakan cara ilmiah untuk mendapatkan data dengan tujuan dan kegunaan tertentu. Berdasarkan hal tersebut terdapat empat kunci yang perlu diperhatikaan yaitu, cara ilmiah, data, dan tujuan dan kegunaan.

Cara ilmiah berarti kegiatan penelitian itu didasarkan pada ciri-ciri keilmuan, yaitu rasional, empiris, dan sitematis. Rasional berarti kegiatan penelitian itu dilakukan dengan caracara yang masuk akal sehingga terjangkau oleh penalaran manusia. Empiris berarti cara-cara yang dilakukan itu tidak dapat diamati oleh indra manusia, sehingga orang lain dapat mengamati dan mengetahui caracara yang digunakan. Sistematis artinya, proses yang digunakan dalam penelitian itu menggunakan langkh-langkah tertentu yang bersifat logis (Sugiyoo, 2016).
Metode penelitian yang digunakan dalam penelitian adalah penelitian kuantitatif. Metode penelitian kuantitatif deskiptif, dapat diartikan sebagai metode penelitian yang berlandaskan pada filsafat positivisme, digunakan untuk meneliti pada populasi dan sampel tertentu, pengumpulan data menggunakan instrument penelitian, analisis data bersifat kuantitatif/statistik, dengan tujuan untuk menguji hipotesis yang telah ditetapkan (Sugiyono, 2016). Variabel penelitian pada dasarnya adalah segala sesuatu yang berbentuk apa saja yang ditetapkan oleh peneliti untuk dipelajari sehingga diperoleh informasi tentang hal tersebut, kemudian ditarik kesimpulannya.

Adapun variable dalam penelitian ini ada dua yaitu variable bebas dan variable terikat. Hubungan Profesionalisme guru merupakan variabel bebas atau variabel (X), 
sedangkan, hasil belajar siswa adalah variabel terikat atau variabel $(\mathrm{X})$.

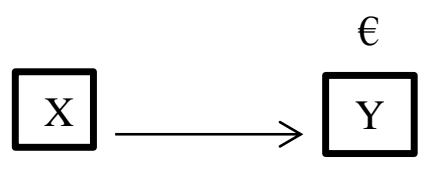

Keterangan :

Y : Hasil Belajar PAI ( variable terikat )

X : Profesionalisme Guru ( Variabel bebas )

$€$ : variable lain yang berpengaruh tapi tidak teliti

Penentuan populasi bagi seorang peneliti memegang peranan penting karena populasi merupakan suatu objek yang dijadikan sumber data. Populasi dalam penelitian ini adalah kelas VIII siswa SMPN 1 Nanggung Bogor yang berjumlah 280 Siswa.

Sampel merupakan bagian dari populasi yang dianggap mewakili populasi. Sampel adalah bagian dari jumlah dan karakteristik yang dimiliki oleh populasi tersebut. Sedangkan, yang akan dijadikan sampel dalam penelitian ini berjumlah $20 \%$ dari jumlah siswa keseluruhan yakni 56 siswa dari total jumlah 280 siswa.

Dalatn rangka menjaring data kedua variable untuk keperluan penelitian ini, maka di pergunakan observasi berupa wawancara untuk mengungkap data variable $X$, dan instrument angket serta nilai raport bidang studi untuk Variabel $Y$.

Wawancara digunakan sebagai teknik pengumpulan data apabila peneliti ingin melakukan studi pendahuluan untuk menemukan permasalahan yang harus diteliti dan juga apabila peneliti ingin mengetahui hal-hal dari responden yang lebih mendalam dan jumlah respondennya sedikit/kecil.

A. Uji Validitas

Validitas merupakan derajad ketepatan antara data yang terjadi pada obyek penelitian dengan 
daya yang dapat dilaporkan

peneliti atau bias dikatakan

pengujian sejauh mana suatu alat

ukur yang digunakan untuk

mengukur tingkatan-tingkatan

kevalidan atau kesohihan suatu

instrument (Sugiyono, 2016).

suatu instrument yang valid atau

sahih memiliki validitas yang tinggi,sebaliknya instrument yang

kurang valid berarti mempunyai

validitas rendah.

Cara pengujian validitas dengan

menghitung korelasi antara skor

masing-masing petranyaan

dengan skor total dengan

menggunakan rumus korelasi

product Moment.

Teknik korelasi produk moment

ini digunakan untuk mencari

hubungan dan membuktikan

hipotesis hubungan dua variabel

berbentuk interval dan ratio.dan

sumber data dari dua variabel atau lebih tersebut adalah sama. Valid

tidaknya suatu item instrument

dapat diketahui dengan

membandingkan indeks korelasi

product moment atau $\mathrm{r}$ hitung

dengan nilai kritisnya dan rumus

product moment yang digunakan

adalah rumus sebagai berikut :

$$
r_{x y}=\frac{n \Sigma X_{i} Y_{i}-\left(\Sigma X_{i}\right)\left(\Sigma Y_{i}\right)}{\sqrt{\left\{n \Sigma X_{i}^{2}-\left(\Sigma X_{i}\right)^{2} \prod^{\prime} n \Sigma Y_{i}^{2}-\left(\Sigma Y_{i}\right)^{2}\right\}}}
$$

Keterangan:

$r_{x y} \quad$ : koefisien korelasi r person

n : jumlah sampel/observasi

x : variabel bebas

y :variable terikat

¿xy : jumlah hasil perkalian antara

skor $\mathrm{x}$ dan $\mathrm{y}$

$\sum \mathrm{x} \quad$ : jumlah seluruh skor $\mathrm{x}$

$\sum y \quad$ : jumlah seluruh skor y

$\sum x^{2}$ : jumlah skor kuadrat $\mathrm{x}^{2}$

$\sum y^{2}$ : jumlah skor kuadrat $\mathrm{y}^{2}$

Uji validitas menunjukkan

sejauh mana suatu instrument mengukur apa yang ingin diukur. 
Instrument dikatakan valid apabila memiliki $r$ hitung $>0,3783$ apabila koefisien korelasi dibawah 0,3783 maka dapat disimpulkan bahwa butir instrument tersebut dikatakan tidak valid.

Adapun 0,3783 didapat dari $\mathrm{r}$ tabel untuk jumlah responden sebanyak 76 dan taraf kesalahan sebesar $10 \% \%$ maka $\mathrm{r}$ tabel $=$ 0,3783 .

Hasil uji validitas pada variabel profesionalisme guru (X) diatas diketahui bahwa terdapat sembilan belas (19) item pernyataan yang Valid dan Enam (6) Item yang Tidak Valid (p2, p6, p7, p9, p10, p14), yang diukur dengan membandingkan nilai $r$ hitung dari masing-masing Item pernyataan terhadap nilai $\mathrm{r}$ tabel (0,378). Dari ke Sembilan belas Item pernyataan yang valid (Lulus uji Validitas ) tersebut dapat dikatakan layak dan dapat dilanjutkan kedalam pengujian selanjutnya.

B. Reabilitas

Realibilitas merupakan kestabilan hasil pengukuran secara repetitif dari masa ke masa. Singaruymbun berpendapat bahwa realibilitas sebagai indikitator validitas atau keakuratan suatu alat ukur. Realibilitas alat ukur dapat diketahui dengan melakukan pengukuran berulang pada gejala yang sama dengan hasil yang sama.

Jika alpha rendah, kemungkinan satu atau beberapa item tidak reliabel. Dengan demikian melakukan identifikasi dengan prosedur analisis per item.

Adapun dalam penelitian ini penulis menggunakan uji realibitas 
Alfa Cronbach. Dengan demikian Instrument dikatakan Reliabel apabila Alpha> 0,757 dinyatakan Reliabel begitupun sebaliknya apabila alpha $<0,757$ maka dinyatakan Tidak Reliabel.

Pengukuran realibitas dilakukan dengan cara one shot atau penguykuran sekali saja kemudian hasilnya dibandingkan dengan pertanyaan lain atau mengukur korelasi antar jawaban pertanyaan. SPSS memberikan fasilitas untuk mengukur realibilitas dengan uji statistik Cronbach Alpha $>0,6$ (Nunnally dalam Ghozali, 2012), Berdasarkan hasil perhitungan diatas,dapat dikatakan bahwa Instrumen Penelitian menunjukan realiabel,karenanilai Alpha Cronbach's 0,6. Jadi instrumen penelitian dinyatakan dapat digunakan.

C. Teknik Analisis data
Dalam penelitian kuantitatif, analisis data merupakan kegiatan dari seluruh responden atau sumber data lain terkumpul. Kegiatan dalam analisis data adalah mengelompokkan data berdasarkan variabel dan jenis respondene, mentabulasi data berdasarkan variabel dari seluruh responden.

Teknik analisis data dalam penelitian kuatitatif menggunakan dibedakan menjadi dua macam yakni statistik deskriftif dan infensial.

\section{Statistik Deskriftif}

Statistik Deskriftif adalah statistik yang digunakan untuk menganalisi data dengan cara mendeskripsikan atau menggambarkan data yang telah terkumpul sebagaimana adanya tanpa bermaksud membuat 


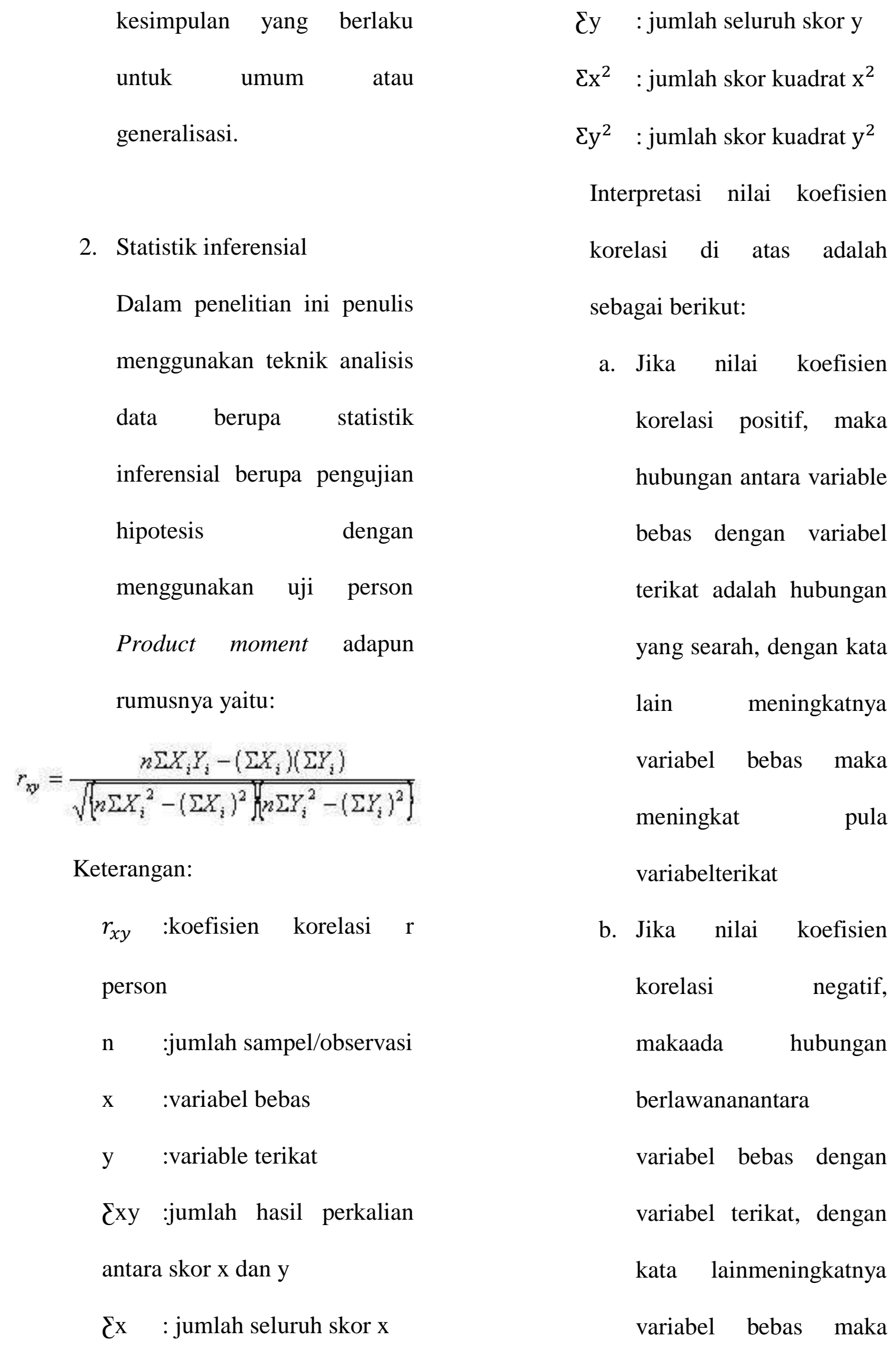


diikuti dengan menurunnyavariabel terikat.

\section{HASIL DAN PEMBAHASAN}

\section{A. Hasil Deskripsi profesionalisme}

\section{Guru}

Dalam menganalisisi data hubungan profesionalisme guru PAI dengan hasil belajar siswa, penelitian mengajukan sebuah pernyataan atau kuesioner kepada 76 orang siswa sebanyak 25 item variabel $\mathrm{x} \quad($ Profesionalisme Guru PAI) dan meninjau hasil Nilai raport siswa untuk melihat Variabel y ( hasil belajar).

Untuk penskoran dalam penelitian ini penulis menggunakan skala model Likert yang di beri skor untuk pernyataan yang bersifat positif $4=$ Selalu,$\quad 3=$ Sering,$\quad 2=$ Kadang Kadang, l=Tidak Pernah. Serta, untuk pernyataan yang bersifat Negatif diberikan skor $1=$ Selalu, $2=$ Sering, 3=Kadang-Kadang, 4=Tidak Pernah.
Adapun data-data yang berkaitan dengan Hubungan Profesionalisme Guru PAI dengan Hasil Belajar Siswa, yang di ambil melalui hasil data angket hasil kepada kelas VIII SMPN 1 Nanggung secara random yang berjumlah 76 siswa dari keseluruhan 260 siswa.

\section{Hasil Deskripsi Hasil belajar}

Dalam menganalisis data yang berkaitan dengan hasil belajar dalam penelitian ini, penulis meninjau dari hasil raport siswa yang bertujuan untuk melihat berapa hasil yang mencapai KKM, rata-rata, nilai tertinggi dan nilai maksimal.

Berdasarkan data hasil belajar pada skripsi menunjukkan bahwa hasil belajar siwa kelas VIII SMPN 1 Nanggung ada pada rata-rata 79,28. Hal ini menggambarkan hasil belajar siswa sudah ada pada ratarata pencapaian KKM yang di gunakan didalam sekolah tersebut. 
Adapun nilai tetinggi siswa yakni 90 dan nilai terendah adalah 70 .

a. Pengujian Hipotesis

\section{Uji Normalitas Data}

Uji Normalitas bertujuan untuk menguji apakah dalam model regresi variabel terikat dan variabel bebas keduanya mempunyai distribusi normal atau tidak. Cara yang bisa ditempuh untuk menguji kenormalan data adalah dengan menggunakan Grafik Normal P-P Plot dengan cara melihat penyebaran datanya. Jika pada grafik tersebut penyebaran datanya mengikuti pola garis lurus, maka datanya normal. Jika pada tabel test of normality dengan menggunakan Kolmogorov Smirnov nilai sig $>0.05$, maka data berdistribusi normal. Adapun Uji Normalitas dalam penelitian ini adalah sebagai berikut: Jika nilai nyata $(\mathrm{p})<$ 0,05 , data dinyatakan tidak normal.

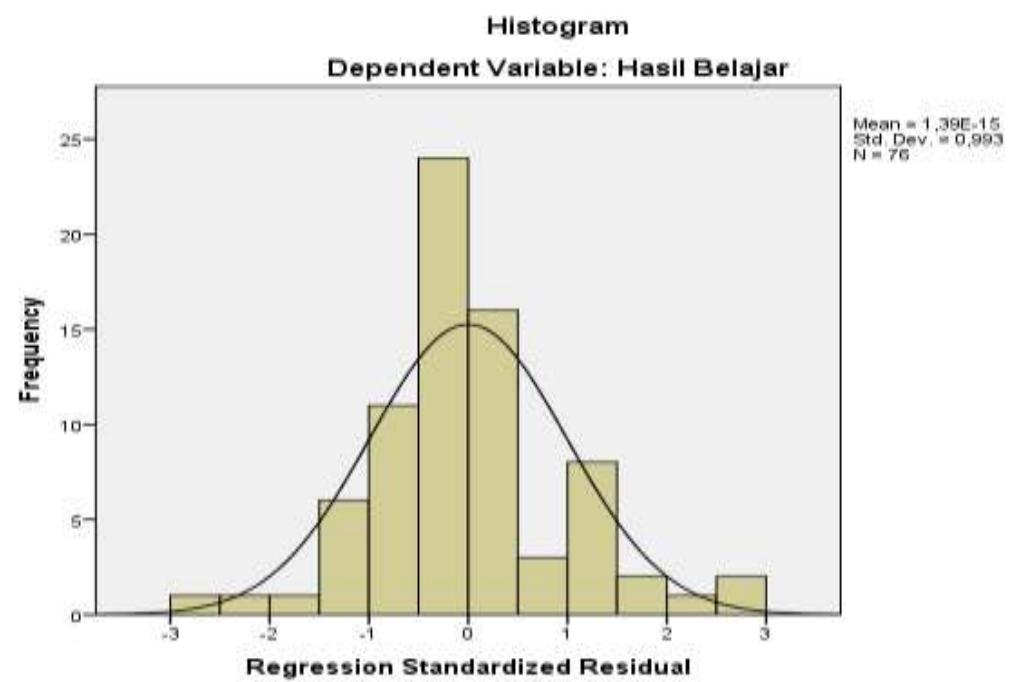




\section{Gambar 1.1}

Grafik Histogram Uji Normalitas Variabel Hasil belajar

(Sumber data: output SPSS yang diolah, 2020)

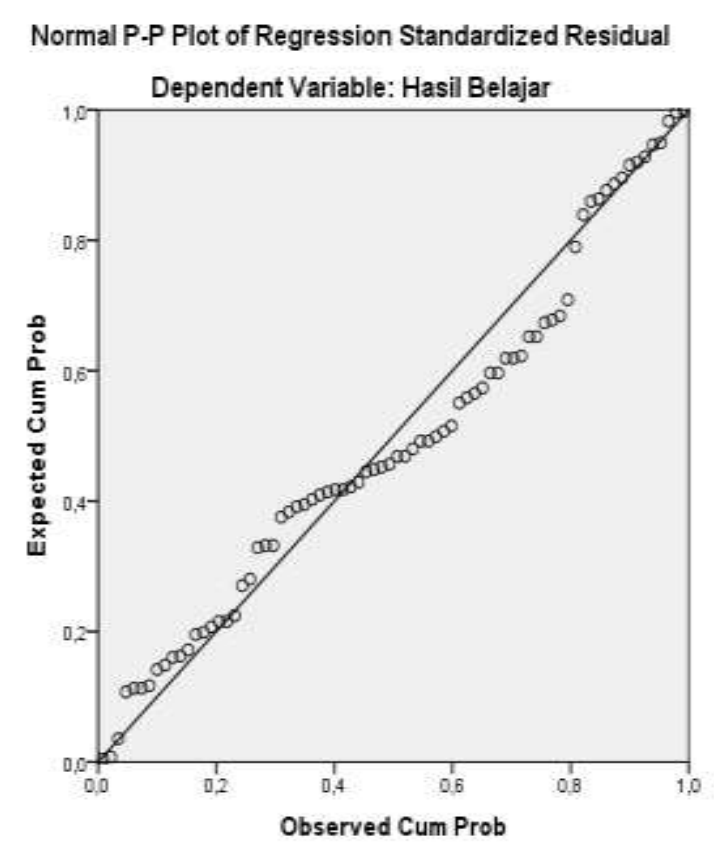

Gambar 1.2

Normal Probability Plot Variabel Hasil Belajar

(Sumber data: output SPSS yang diolah, 2020)

Berdasarkan pada grafik

histogram, residual data telah

menunjukkan kurva normal yang

membentuk lonceng sempurna.

Begitu pula, pada grafik normal

$P-P$ Plot residual penyebaran data

belum terlalu garis normal (garis

lurus) dan mendekati garis.

Dengan demikian, residual data berdistribusi normal dan model regresi telah memenuhi asumsi normalitas serta layak digunakan dalam penelitian ini.

2. Uji Koefisien Korelasi

Uji koefisien korelasi digunakan untuk menguji arah hubungan variabel bebas dengan variabel terikat. Untuk 
mengetahui apakah secara signifikan terdapat korelasi positif antara komunikasi orang tua dengan siswa terhadap kepribadian siswa.

Berdasarkan data pada hasil penelitian terlihat koefisien korelasi Pearson product moment komunikasi orang tua sebesar 0.242 Artinya besar korelasi atau hubungan antara variabel Hasil Belajar dengan Profesionalisme Guru ialah sebesar 0,242 atau rendah karena mendekati angka 0.

Korelasi pearson product moment mempunyai jarak antara -1 sampai dengan +1 . Jika koefisien adalah -1 maka kedua variabel yang diteliti mempunyai hubungan linier sempurna negatif. Jika koefisien korelasi adalah +1 maka kedua variabel yang diteliti mempunyai hubungan linier sempurna positif.

Jika koefisien menunjukkan angka 0 maka tidak terdapat hubungan antara dua variabel yang dikaji (Sarwono, 2012).

Berdasarkan tabel di atas hubungan profesionalisme guru dengan hasil belajar signifikan karena angka signifikansi sebesar $0,018<0,10$. Arah korelasi dapat dilihat dari angka koefisien korelasi hasilnya positif atau negatif.Sesuai dengan hasil analisis, koeefisien korelasi profesionalisme Guru bernilai positif yaitu 0,242 , maka korelasi kedua variabel bersifat searah. Artinya jika komukikasi orang tua tinggi maka Hasil belajar siswa juga tinggi. Secara manual dapat dihitung dengan menggunakan rumus, hasil hitungan secara manual adalah sebagai berikut : 


$$
\begin{aligned}
& \text { diperoleh } \quad \mathrm{N}=76, \quad \sum \mathrm{X}=6026, \quad \text { maka dapat dicari angket korelasi } \\
& \sum \mathrm{Y}=6025, \quad \mathrm{X}_{2}=\quad \mathbf{4 8 3 . 1 1 4}, \quad \text { (rxy) dengan menggunakan } \\
& \mathrm{Y}_{2}=\mathbf{4 7 8 . 6 0 7}, \quad \sum X Y=\mathbf{4 7 8 . 2 6 7}, \quad \text { rumus sebagai berikut: } \\
& \begin{array}{l}
\frac{\mathrm{N} \cdot \Sigma X Y-(\Sigma X \cdot \Sigma Y)}{\sqrt{\left[\mathrm{N} \cdot \Sigma X^{2}-(\Sigma X)^{2}\right]\left[\mathrm{N} \cdot \Sigma Y^{2}-(\Sigma Y)^{2}\right]}} \\
\mathrm{r}_{x y}=\frac{76 \cdot(478267)-(6026)(6025)}{\sqrt{\left[(76)(483114)-(6026)^{2}\right]\left[76 .\left(478607-(6025)^{2}\right.\right.}} \\
\mathrm{r}_{x y}=\frac{76 .(478267)-(6026)(6025)}{\sqrt{[76 .(483114)-36312676][76 .(478607)-(36300625)]}} \\
\mathrm{r}_{x y}=\frac{36348292-36306650}{\sqrt{[36716664-36312676] x[36374132-36300625]}} \\
\mathrm{r}_{x y}=\frac{41642}{\sqrt{(403988)(73507)}} \\
\mathrm{r}_{x y}=\frac{41642}{\sqrt{29695945916}} \\
\mathrm{r}_{x y}=\frac{41642}{172325} \\
\mathrm{r}_{x y}=\mathbf{0 , 2 4 2}
\end{array}
\end{aligned}
$$

Berdasarkan hasil hitungan di atas maka didapatkan nilai r-hitung yaitu sebesar 0,242 , sedangkan nilai r-tabel pada jumlah 76 yaitu $0,0,1901$. Sesuai dengan ketentuan apabila nilai r-hitung lebih besar dari nilai r-tabel $(0,242>0,1901)$ maka terdapat hubungan yang sedang antara variable $\mathrm{X}$ atau profesionalisme guru dan variable $\mathrm{Y}$ atau Hasil Belajar siswa.

Tabel VII

Interprestasi Koefisien Korelasi

\begin{tabular}{|l|l|}
\hline Interval & Kategori \\
\hline
\end{tabular}




\begin{tabular}{|c|c|}
\hline $0,00-0,19$ & Sangat Rendah \\
\hline $0,20-0,39$ & Rendah \\
\hline $0,40-0,69$ & Sedang \\
\hline $0,70-0,89$ & Kuat \\
\hline $0,90-1,00$ & Sangat Kuat \\
\hline
\end{tabular}

Sumber:

Sugiyono, 2013

3. Uji Koefisien Determinasi

Berdasarkan hasil

Koefisien determinasi

merupakan

pengkuadratan korelasi

secara simultan (r) anatara

veriabel bebas $(\mathrm{X})$ dengan

variabel terikat $(\mathrm{Y})$ guna

menghitung seberapa jauh

hubungan antara keduanya

atau koefisien determin.

Hasil perhitungan

determinasi adalah sebagai

berikut:

$$
\begin{aligned}
K D & =r^{2} X 100 \% \\
& =(0,242)^{2} \times 100 \% \\
& =0,058564 \times 100 \% \\
& =5,8564 \%
\end{aligned}
$$

perhitungan KD dari $100 \%$

dapat disimpulkan bahwa

hubungan antara variabel

$\mathrm{X}$ dan variabel $\mathrm{Y}$ memiliki

pengaruh yang signifikan.

Adapun

koefisien

penentunya yaitu $\left(\mathrm{r}^{2}\right)$ yang

berarti adanya hubungan

antara profesionalisme

guru PAI dengan hasil

belajar siswa kelas VII

SMPN 1 NANGGUNG,

kontribusi profesionalisme

guru PAI terhadap HASIL

BELAJAR siswa sebesar

$5,8564 \% \quad$ sedangkan

$94,1436 \% \quad$ lainnya 
dipengaruhi oleh faktor-

faktor lainnya seperti :

a. Faktor Internal (factor

yang berasal dari dalm

diri siswa), yakni

keadaan/kondisi dan

rohani siswa,

b. Faktor Eksternal

factor yang berasal

dari luar diri siwa),

yakni kondisi

lingkungan disekitar

siswa,

c. Faktor pendekatan

Belajar (approach to

learning), yakni jenis

upaya belajar siswa

yang meliputi strategi

dan metode yang

digunakan siswa

untuk melakukan

kegiatan mempelajari

materi-materi

pelajaran
Dengan demikian

berdasarkan hasil penelitian

yang dilakukan di kelas VIII

SMPN 1 Nanggung dapat

ditarik kesimpulan bahwa

terdapat hubungan antara

profesionalisme guru PAI

dengan hasil belajar siswa

hanya memberikan kontribusi

yang relatif rendah.

4. Uji Hipotesis

Untuk

menguji

hubungan profesionalisme guru

dengan hasil Belajar siswa

kelas VIII SMPN 1 Nanggung

signifikan atau tidak, dalam

penelitian ini menggunakan

nilai koefisien korelasi.

Berdasarkan hasil penelitian

ini diperoleh nilai koefisien

korelasi sebesar 0,242 dengan

nilai sig 0,019 artinya terdapat

hubungan positif yang sig

antara profesionalisme guru 


dengan hasil belajar siswa.
Kuat hubungan antara
profesionalisme dengan hasil
belajar ada pada kategori
rendah. Dengan demikian
pengujian menunjukkan
"terdapat hubungan yang
signifikan antara
Profesionalisme guru PAI
dengan hasil belajar siswa
kelas VIII SMPN 1 Nanggung
dengan kategori rendah.

\section{B. Pembahasan}

1. Profesionalisme Guru

$$
\text { Professional guru adalah }
$$

$$
\begin{aligned}
& \text { orang yang khusus menggeluti } \\
& \text { pekerjaan mengajar dalam } \\
& \text { kehidupannya dengan segala } \\
& \text { kemampuan keguruan yang } \\
& \text { dimilikinya, dimana } \\
& \text { kemanapun itu meliputi : telah } \\
& \text { mengikuti pendidikan secara } \\
& \text { baik, ahli dalam bidang } \\
& \text { materi,maupun penguasaan }
\end{aligned}
$$

tekhnik menyampaikannya, memiliki komitmen terhadap upaya perubahan, mampu melihat persoalan jauh kedepan dalam menjawab tantangantantangan yang dihadapi kegiatan pendidikan, dan melaksanakan kegiatan mengajar dengan penuh rasa tanggungjawab tanpa pamrih sesuai dengan tingkat keahliannya.

$$
\text { Berdasarkan deskripsi }
$$

hasil penelitian, penulis dapat mendeskripsikan

profesionalisme guru PAI SMPN 1 Nanggung sebagai berikut :

a. Guru PAI mampu merumuskan serta menjelasakan tentang tujuan belajar yang akan dicapai melalui pembelajaran sebelum 


\begin{tabular}{|c|c|}
\hline menjelaskan materi, hal ini & pelaksanaan \\
\hline sangat penting karena guru & pembelajaran, \\
\hline yang professional harus & belajar, \\
\hline memahami dasar kemana & pengembangan \\
\hline pembelajaran akan di & didik \\
\hline capai sehingga siswa tidak & mengaktualisasikan \\
\hline bingung ke arah mana & berbagai potensi yang \\
\hline pembelajaran & dimilikinya.dalam hal ini \\
\hline dibawa. Maka dari itu & guru PAI harus memiliki \\
\hline seorang guru professional & kompetensi tersebut. \\
\hline harus mampu melakukan & c. Guru PAI \\
\hline hal tersebut. & memberikan soal sesuai \\
\hline Guru PAI mampu & materi pembelajaran dan \\
\hline menjelaskan ,menguasai & menjawab pertanyaan \\
\hline materi pembelajaran serta & yang diajukan oleh siswa. \\
\hline dapat meneglola kelas & Hal ini bertujuan penting \\
\hline dengan baik, hal ini & untuk siswa supaya dapat \\
\hline berkaitan dengan aspek- & mengisi soal dengan \\
\hline kompetensi & jawaban yang sesuai \\
\hline professional & dengan materi dan apabila \\
\hline kompetensi & mengajukan \\
\hline yang berarti kemampuan & pertanyaan, seorang guru \\
\hline pemahaman & professional harus mampu \\
\hline
\end{tabular}




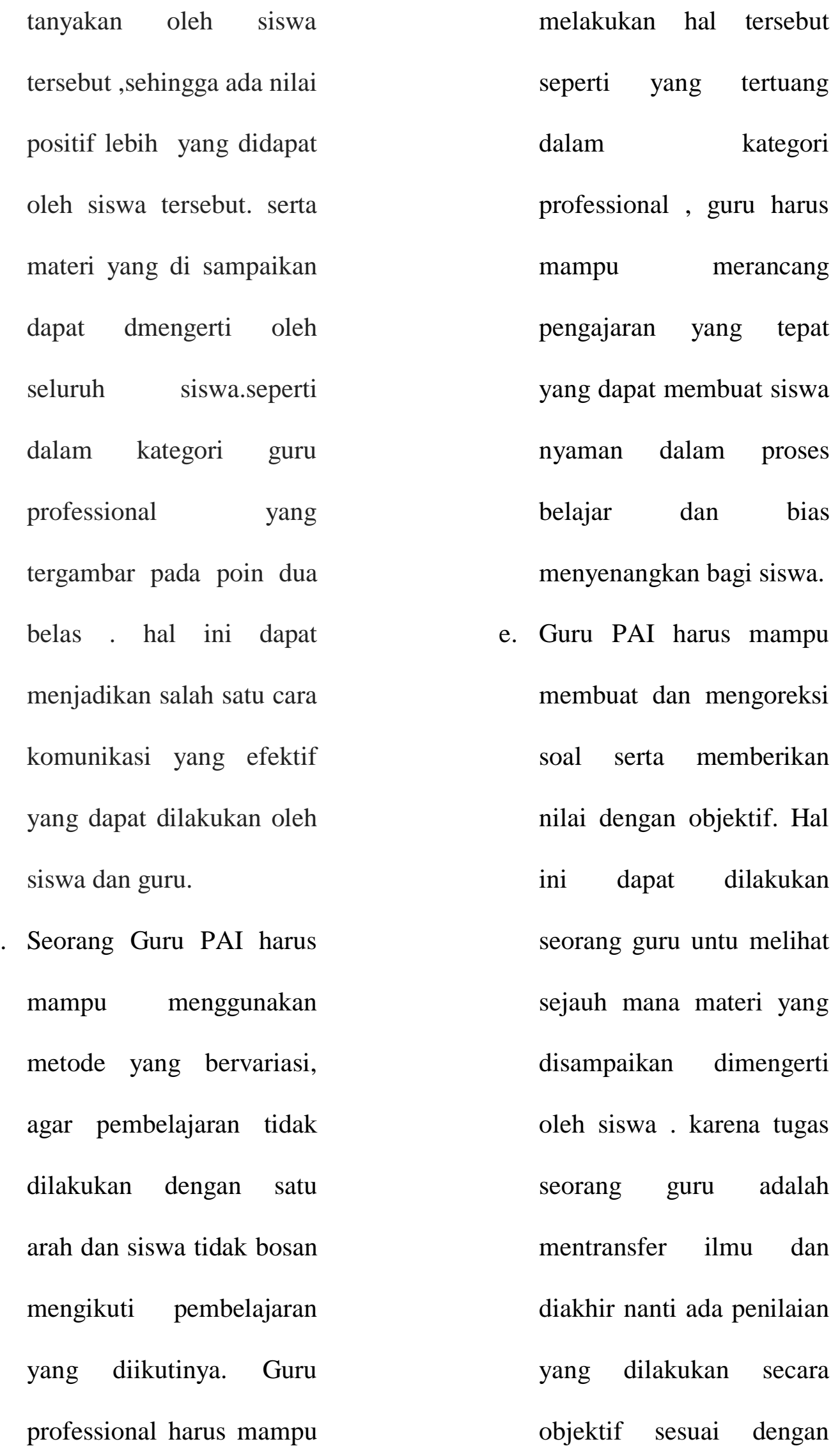


pemahaman siswa masing-

masing.

f. Seorang guru memiliki arti adalah ujung tombak bagi kehidupan bangsa ,guru adalah seorang yang digugu dan ditiru, artinya apapun yang dilakukan oleh guru akan di contoh atau diikuti oleh siswa, maka dari itu guru PAI harus mampu menjadi teladan bagi seluruh siswa seperti dalam aspek kompetensi professional disebutkan guru harus mempunyai kompetensi kepribadian yang berupa disiplin, arif dan berwibawa dan memiliki sifat lain-lain sesuai dengan tata tertib yang sudah ditentukan.

2. Hasil belajar
Hasil Belajar adalah kompetensi atau kemampuan yang diperoleh peserta didik berkebutuhan khusus melalui kegiatan belajar.Kegiatan belajar merupakan satu kesatuan dengan kegiatan mengajar. Belajar itu sendiri merupakan suatu proses dari peserta didik berkebutuhan khusus yang berusaha untuk memperoleh suatu bentuk perubahan prilaku yang relative menetap sesuai dengan karakteristiknya dan kebutuhan khususnya.

Hasil belajar merupakan keterlibatan dari beberapa faktor dengan proses belajar mengajar dikelas. Dengan memahami dan menggunakan faktor tersebut sebagai landasan dasar dalam proses belajar mengajar dikelas, maka 
siswa diharapkan mampu

mencapai hasil belajar yang

baik disekolah. Dengan

demikian, hasil belajar siswa

mampu tercapai sesuai harapan

yang telah ditentukan oleh

sekolah.

Berdasarkan deskripsi

hasil penelitian, penulis dapat

mendeskripsikan Hasil belajar

kelas VIII PAI SMPN 1

Nanggung sebagai berikut :

Hasil belajar siswa kelas

VIII SMPN 1 Nanggung,

sudah mencapai KKM dan

melebihi KKM , hal ini

menggambarkan bahwa materi

yang disampaikan oleh guru

dapat di mengerti oleh siswa

baik itu dalam nilai kognitif,

afektif atau psikomotorik.

Dapat dilihat pada nilai rata-

rata 79,28 dan hal ini

mencerminkan bahwa rata-rata hasil belajar siswa telah

mencapai KKM,adapun nilai

teringgi dalam hasil Belajar

siswa kelas VIII SMPN 1

Nanggung yakni 90 dan nilai

terkecil ada pada rentang nilai

70.

\section{KESIMPULAN}

Berdasarkan analisi data hasil penelitian Hubungan profesionalisme Guru PAI ( variabel $\mathrm{x}$ ) dan hasil Belajar PAI siswa ( variabel y) kelas VIII SMPN 1 Nanggung dapat disimpulkan hal-hal sebagai berikut:

1. Guru PAI kelas VIII SMPN 1 Nanggung mempunyai tingkat profesionalisme. Hal ini ditandai dengan guru PAI mampu melakukan aspek -aspek menjadi guru professional dan mengikuti kategori guru professional sehingga hal ini menjadi bekal untuk seorang 
guru menjadikan dirinya sebai guru professional.

2. Hasil belajar PAI siswa kelas VIII SMPN 1 Nanggung berjalan dengan cukup baik . hal ini ditandai dengan nilai rata-rat diatas KKM ( Kriteria Ketuntasan Minimal ), yakni dengan rta-rata 79,28, dan nilai tertinggi ada pada nilai 90 dan nilai terndah pada nilai 70 . Sehingga dapat dikatakan bahwa hasil belajar siswa sudah cukup baik dalam segi afektif,kognitif atau psikomotorik.

3. Terdapat hubungan poistif antara profesionalisme guru PAI dengan hasil belajar PAI kelas VIII SMPN 1 Nanggung. diperoleh nilai koefisien korelasi sebesar 0,242 dengan nilai sig 0,019 artinya terdapat hubungan positif yang sig antara profesionalisme guru dengan hasil belajar siswa. Kuat hubungan antara profesionalisme dengan hasil belajar ada pada kategori rendah.

Profesionalisme memiliki konntribusi sebesar $\quad 5,8564 \%$ sedangkan $94,1436 \%$ lainnya dipengaruhi oleh faktor-faktor lainnya.

\section{DAFTAR PUSTAKA}

Dedy Kustawan. 2013. Analisis Hasil Belajar, Jakarta : PT. Luxima metro media.

Dewantara, K Hadjar.2013. Pemikiran,Konsepsi,

Keteladanan,Sikap Merdeka Yogyakarta : Majelis Luhur Persatuan Taman Siswa :2013.

Hamdani. 2011. Strategi Belajar Mengajar, Bandung : Pustaka Setia

Kustawan, Dedy. 2013. Analisis Hasil Belajar, Jakarta : PT. Luxima metro media

Nasution.2011. Sosiologi Pendidikan, Jakarta : Bumi Aksara

Pupuh Fathurohman Dan Aa Suryana.2012. Guru

Profesional, Bandung, :PT. Refika Aditama

Sugiyono.2016. Metode Penelitian, Bandung: Alfabeta. 
Syah, Muhibbin. Psikologi Pendidikan,

Bandung: Remaja Rosdakarya.

Syaiful bahri djamarah dan Aswan

Zain. (2010). Strategi belajar

mengajar, Jakarta: PT Bineka

cipta. 
